\title{
Weathering Characteristics of Sloping Fields in the Three Gorges Reservoir Area, China ${ }^{* 1}$
}

\author{
JIANG Hong-Tao ${ }^{1}, \mathrm{XU}$ Fei-Fei ${ }^{1}, \mathrm{CAI} \mathrm{Yi}^{2}$ and YANG Da-Yuan ${ }^{1}$ \\ ${ }^{1}$ Department of Urban and Resources Science, Nanjing University, Nanjing 210093 (China). E-mail: hongtaojiang@sina. \\ com.cn \\ ${ }^{2}$ Department of Earth Science, Nanjing University, Nanjing 210093 (China)
}

(Received June 10, 2005; revised November 22, 2005)

\begin{abstract}
For the purpose of understanding the weathering characteristics of surface layers in purple mudstone sloping fields of the Three Gorges Reservoir area of China, oxide content of major elements, composition of clay minerals, magnetic susceptibility, and difference in weathering characteristics of surface layers under different slope gradients were determined. The results showed that the oxide content of $\mathrm{Si}, \mathrm{Al}$, and Fe ranged from $60 \%$ to $75 \%$ and the weathering coefficient with depth showed no trend along the slope gradient. Also, for gentle $\left(10^{\circ}\right.$ and $\left.15^{\circ}\right)$ and intermediate $\left(25^{\circ}\right.$ and $\left.40^{\circ}\right)$ slopes the clay relative diffraction peak for kaolinite at the surface between $0-10 \mathrm{~cm}$ and $10-20 \mathrm{~cm}$ declined with an increase in slope gradient, while the relative diffraction peak for kaolinite in weathered layers on steep slopes $\left(50^{\circ}\right.$ and $\left.60^{\circ}\right)$ disappeared altogether. Magnetic susceptibility decreased with increasing depth and, for a given depth layer, decreased with an increase in slope gradient. Analysis of the oxide content, weathering coefficients, clay minerals, and magnetic susceptibility showed that in the Three Gorges Reservoir area, the pedogenesis of the weathering layer in purple mudstone sloping fields was weak with weaker soil formation going from gentle slope to steep slope.
\end{abstract}

Key Words: purple mudstone, sloping field, Three Gorges, weathering

Weathering characteristics in sloping fields has been a subject of study for many researchers (Clark and Small, 1982; Yang and Lu, 1992; Easterbrook, 1993; Liang et al., 1993; He and Tang, 1998; Liu et al., 1996; Lu, 2000; Moreau and Petard, 2004; Rech et al., 2001; Shi et al., 1998, 2002; Yokota and Iwamatsu, 2002; Atkinson et al., 2003; Zhang et al., 2004; Allen, 2005; He et al., 2005). Much work has also been done on the weathering characteristics in the sloping fields of the Three Gorges Reservoir area in China (Chong et al., 2002; Cai et al., 1996; Compiling Committee of Fengjie County in Sichuan Province, 1995; Liu et al., 1991; Shi et al., 1991; Zhang et al., 2002). However, most of the research achievements have focused on the formation characteristics, nutrients, land erosion of purple mudstone slopes in the Three Gorges, while only a few studies have focused on its weathering degree and characteristics. Therefore, it is necessary to further research the weathering characteristics of purple mudstone in order to understand how sloping land develops.

This research studied the surface layers of different purple mudstone sloping fields in the Caotang River Basin in Fengjie County of the Three Gorges Reservoir area. The fieldwork and sampling analysis of oxide content of major elements, clay mineral composition, magnetic susceptibility, and differences in weathering characteristics of surface layers under different gradients were determined to provide a basis for characterizing geomorphology, potential resource use, and an evaluation of the overall engineering geological conditions.

\section{MATERIALS AND METHODS}

\section{Site description}

The Three Gorges Reservoir area studied herein covers Yichang City, Zigui, Xingshan, and Badong

\footnotetext{
*1 Project supported by the National Natural Science Foundation of China (No.40272126) and the Nanjing University Startup Foundation for Young Scholar (No. 0209005116).
} 
counties in Hubei Province, and Wushan Mountain, Wuxi, Fengjie, Yunyang, Wanzhou, Kaixian, Zhongxian, Fengdu, Shizhu, Fuling, Wuling, Changshou, Yubei, Banan counties, Chongqing Municipality and Jiangjin City, which altogether comprise 20 counties, cities and districts. The total area is $5.67 \times 10^{4} \mathrm{~km}^{2}$, of which $600 \mathrm{~km}^{2}$ land area is submerged by the reservoir.

The Caotang River, located in Fengjie County of Chongqing Municipality, is the main stream on the northern embankment of the Yangtze River, and it is under the jurisdiction of Baidi, Caotang, and Fenghe in Fengjie County. The river has two main tributaries, namely, the Fenghe River and the Shima River. The main tributary is about $33.3 \mathrm{~km}$ long with an average gradient of $0.665 \%$; the river basin area is $394.8 \mathrm{~km}^{2}$; the average flow is $7.51 \mathrm{~m}^{3} \mathrm{~s}^{-1}$; and the total yearly flow is 0.237 billion $\mathrm{m}^{3}$. There are abundant water and rich river networks in this area, and the average river network density is 0.79 $\mathrm{km}^{-2}$. In this area the strata are composed of sedimentary rock, mostly belonging to the Badong group of the Middle Triassic. The geomorphological type is low mountain river basin. The climate here is mid-subtropical humid monsoon with an average temperature of $15{ }^{\circ} \mathrm{C}$ and average rainfall of 1200 $\mathrm{mm}$. The river basin consists mostly of steep slopes and dry land, or bushy grass slopes. As a result the vegetation is severely damaged with large amounts of land and water lost through frequent mudflows on the slopes and in the gorges area that raise the riverbed every year (Zheng and Shen, 1998).

\section{Sampling and sample analysis}

For the purpose of this study conducted in the Caotang River Basin, the slope was divided into three classes according to different slope gradients and six slopes were selected, that is, gentle slopes $\left(10^{\circ}\right.$ and $15^{\circ}$ gradient), intermediate slopes $\left(25^{\circ}\right.$ and $\left.40^{\circ}\right)$, and steep slopes $\left(50^{\circ}\right.$ and $\left.60^{\circ}\right)$. A sampling cylinder with an inner diameter of $9.5 \mathrm{~cm}$ and height of $50 \mathrm{~cm}$ was used to bore vertically into the weathering layers to obtain cylindrical soil samples. The sampling interval for each boring was $6 \mathrm{~cm}$ in gentle slope areas, $4 \mathrm{~cm}$ in intermediate slope areas, and $3 \mathrm{~cm}$ in steep slope areas. From each boring seven samples were collected, plus six surface layer soil samples on the six slopes, or totally 48 samples.

After soil samples were air-dried, ground, and then pressed onto the glass slices, the oxide content of major elements of the samples was examined by a VF320 X-ray fluorescence spectrum machine, produced by Shimadzu Company in Japan. Air-dried samples were rubbed and were then put into $10 \mathrm{~mL}$ cylindrical plastic boxes for pressing and weighing. Then they were tested by a Bartington Magnetometer MS2 type magnetic machine, produced in Germany with a low working frequency of 0.4 $\mathrm{kHz}$. For an X-ray diffractometry examination a D/max-RA X-ray machine produced by Shimadzu Company in Japan was used to test the mineral content in clay. The magnetic testing work was conducted in the Nanjing Institute of Geography and Limnology, Chinese Academy of Sciences. Other testing work was performed at the Modern Analysis Center of Nanjing University, China.

\section{RESULTS}

\section{Chemical composition and weathering coefficient}

The composition of weathering layers in the study area were mostly oxides of $\mathrm{Si}, \mathrm{Al}$, and $\mathrm{Ca}$, which accounted for $60 \%-75 \%$ of the total, followed by $\mathrm{Fe}_{2} \mathrm{O}_{3}, \mathrm{MgO}, \mathrm{K}_{2} \mathrm{O}$, and $\mathrm{Na}_{2} \mathrm{O}$ (Table I). There were also many secondary sediments of $\mathrm{CaCO}_{3}$ (almost 35\%), usually found in the $25^{\circ}$ intermediate slope. Additionally, with slope gradients of $10^{\circ}$ and mostly in the bottom layer (depth $>30 \mathrm{~cm}$ ), there were some $\mathrm{CaCO}_{3}$ sediments with the seepage. In the weathering layer of this same gentle slope, with an increase in depth there were some slight differences in oxide content, however there was no obvious trend.

For a given slope gradient, with increasing depth the weathering coefficients of silicon-aluminum, aluminum-iron, and silicon-iron changed slightly with no obvious trend. However, with different slope gradients (Table I) differences in chemical element movement was noted: from gentle, intermediate, and steep slopes, the average coefficients for $\mathrm{SiO}_{2} / \mathrm{Al}_{2} \mathrm{O}_{3}$ were 6.14, 6.04, and 6.39, respectively; for 
$\mathrm{Al}_{2} \mathrm{O}_{3} / \mathrm{Fe}_{2} \mathrm{O}_{3} 4.68,5.18$, and 5.05, correspondingly; for $\mathrm{R}_{2} \mathrm{O}_{3} / \mathrm{SiO}_{2} 0.19,0.19$, and 0.18 , in that order; and for $\mathrm{SiO}_{2} / \mathrm{Fe}_{2} \mathrm{O}_{3} 28.99,29.64$, and 32.33, respectively.

\section{TABLE I}

Mean oxide contents of major elements and weathering coefficients in the weathering layer for different slope gradients

\begin{tabular}{|c|c|c|c|c|c|c|c|c|c|c|c|c|}
\hline \multirow{2}{*}{$\begin{array}{l}\text { Slope } \\
\text { gradient }\end{array}$} & \multirow[t]{2}{*}{ Layer ${ }^{a)}$} & \multicolumn{7}{|l|}{ Oxide } & \multicolumn{4}{|c|}{ Weathering coefficient } \\
\hline & & $\mathrm{SiO}_{2}$ & $\mathrm{Al}_{2} \mathrm{O}_{3}$ & ${ }_{3} \mathrm{Fe}_{2} \mathrm{O}_{3}$ & $\mathrm{CaO}$ & $\mathrm{MgO}$ & $\mathrm{K}_{2} \mathrm{O}$ & $\mathrm{Na}_{2} \mathrm{O}$ & $\mathrm{SiO}_{2} / \mathrm{Al}_{2} \mathrm{O}_{3}$ & $\mathrm{Al}_{2} \mathrm{O}_{3} / \mathrm{Fe}_{2} \mathrm{O}_{3}$ & $\mathrm{R}_{2} \mathrm{O}_{3} / \mathrm{SiO}_{2}$ & $\mathrm{SiO}_{2} / \mathrm{Fe}_{2} \mathrm{O}_{3}$ \\
\hline & & & & & $\%$ & & & & & & & \\
\hline \multirow[t]{4}{*}{$10^{\circ}$} & I & 36.73 & 13.21 & 4.92 & 17.12 & 1.48 & 1.63 & 0.02 & 6.12 & 4.84 & 0.19 & 29.69 \\
\hline & II & 28.73 & 10.58 & 3.66 & 26.40 & 1.36 & 1.47 & 0.02 & 6.14 & 4.59 & 0.19 & 29.22 \\
\hline & III & 33.94 & 12.17 & 4.37 & 20.77 & 1.36 & 1.64 & 0.02 & 6.13 & 4.57 & 0.19 & 28.01 \\
\hline & IV & 31.12 & 11.61 & 3.78 & 24.28 & 1.60 & 1.60 & 0.03 & 6.08 & 4.69 & 0.19 & 28.57 \\
\hline \multirow[t]{4}{*}{$15^{\circ}$} & I & 35.82 & 9.89 & 3.54 & 21.92 & 1.66 & 1.73 & 0.07 & 6.15 & 4.38 & 0.19 & 28.57 \\
\hline & II & 39.05 & 10.81 & 3.69 & 19.22 & 1.82 & 1.92 & 0.07 & 6.15 & 4.78 & 0.20 & 29.12 \\
\hline & III & 41.61 & 11.49 & 3.81 & 17.55 & 1.96 & 1.95 & 0.05 & 6.16 & 4.80 & 0.19 & 29.10 \\
\hline & IV & 38.66 & 10.73 & 3.68 & 19.72 & 1.82 & 1.90 & 0.06 & 6.16 & 4.81 & 0.19 & 29.65 \\
\hline \multirow[t]{3}{*}{$25^{\circ}$} & I & 20.40 & 6.78 & 1.68 & 35.17 & 1.00 & 1.19 & 0.02 & 5.46 & 4.29 & 0.20 & 38.91 \\
\hline & II & 19.96 & 7.35 & 2.10 & 35.66 & 1.06 & 1.21 & 0.02 & 6.17 & 4.78 & 0.19 & 26.47 \\
\hline & III & 22.03 & 7.74 & 2.12 & 34.10 & 1.12 & 1.32 & 0.02 & 6.42 & 7.11 & 0.19 & 27.87 \\
\hline \multirow[t]{3}{*}{$40^{\circ}$} & I & 37.30 & 10.93 & 2.81 & 20.43 & 2.07 & 2.19 & 0.15 & 5.80 & 4.33 & 0.20 & 27.24 \\
\hline & II & 50.74 & 13.98 & 5.11 & 10.13 & 2.33 & 3.00 & 0.25 & 6.14 & 4.45 & 0.20 & 27.94 \\
\hline & III & 55.41 & 14.65 & 5.30 & 6.60 & 2.53 & 3.14 & 0.34 & 6.26 & 6.10 & 0.19 & 29.40 \\
\hline \multirow[t]{2}{*}{$50^{\circ}$} & I & 24.80 & 9.79 & 2.18 & 26.50 & 4.87 & 1.96 & 0.02 & 6.34 & 5.24 & 0.18 & 33.26 \\
\hline & II & 27.96 & 10.16 & 2.92 & 23.98 & 5.17 & 2.00 & 0.03 & 6.42 & 4.94 & 0.18 & 31.77 \\
\hline \multirow[t]{2}{*}{$60^{\circ}$} & I & 40.45 & 10.54 & 3.28 & 19.48 & 2.20 & 2.08 & 0.18 & 6.38 & 4.76 & 0.18 & 30.45 \\
\hline & II & 39.40 & 10.44 & 3.31 & 20.15 & 2.24 & 2.08 & 0.18 & 6.41 & 5.27 & 0.18 & 33.83 \\
\hline
\end{tabular}

a) Depth of sampling layer: $I$ is $0-10 \mathrm{~cm}, I I$ is $10-20 \mathrm{~cm}$, III is $20-30 \mathrm{~cm}$, and IV is greater than $30 \mathrm{~cm}$.

\section{Clay minerals}

Clay minerals in the weathering layer mostly consisted of mica, vermiculite-montmorillonite, and kaolinite. Besides clay minerals, there were also some quartz and calcite. The clay mineral content changed with depth and slope gradient as the relative height of the diffraction peak for the clay mineral indicated (Table II).

\section{TABLE II}

Heights of diffraction peaks for clay minerals in the weathering layers for different slope gradients and depths

\begin{tabular}{|c|c|c|c|c|c|c|c|}
\hline \multirow[t]{2}{*}{ Mineral type } & \multirow[t]{2}{*}{ Layer $^{a)}$} & \multicolumn{6}{|c|}{ Slope gradient } \\
\hline & & $10^{\circ}$ & $15^{\circ}$ & $25^{\circ}$ & $40^{\circ}$ & $50^{\circ}$ & $60^{\circ}$ \\
\hline \multirow[t]{5}{*}{ Mica } & Surface & $2.6^{\mathrm{b})}$ & 2.3 & 2.0 & 1.2 & 1.1 & 1.0 \\
\hline & I & 2.5 & 2.6 & 2.0 & 2.0 & 0.7 & 0.8 \\
\hline & II & 3.4 & 3.2 & 2.1 & 1.0 & - & - \\
\hline & III & 3.4 & 3.2 & 2.3 & 1.0 & - & - \\
\hline & IV & 3.1 & 3.1 & 2.5 & 0.9 & - & - \\
\hline \multirow{4}{*}{$\begin{array}{l}\text { Vermiculite- } \\
\text { montmorillonite }\end{array}$} & Surface & 2.6 & 2.7 & 2.4 & 2.3 & 2.0 & 2.0 \\
\hline & I & 2.9 & 2.8 & 2.6 & 2.5 & 1.5 & 1.4 \\
\hline & II & 4.1 & 4.1 & 3.0 & 1.9 & 1.1 & 1.4 \\
\hline & III & 4.0 & 4.2 & 2.7 & 1.9 & 1.0 & 1.3 \\
\hline \multirow[t]{3}{*}{ Kaolinite } & Surface & 1.4 & 1.3 & 1.1 & 1.0 & - & - \\
\hline & I & 1.3 & 1.2 & 1.1 & 0.7 & - & - \\
\hline & II & 0.9 & 0.9 & 0.7 & 0.6 & - & - \\
\hline
\end{tabular}

a) Depth of sampling layer: I is $0-10 \mathrm{~cm}$, II is $10-20 \mathrm{~cm}$, III is $20-30 \mathrm{~cm}$, and IV is greater than $30 \mathrm{~cm}$;

b) The numbers in the table are average values. 
Within the same gradient but at different depths, the diffraction peak heights of the clay mineral varied. For mica and vermiculite-montmorillonite, in the gentle slope area $\left(10^{\circ}\right.$ and $\left.15^{\circ}\right)$ the heights of the diffraction peaks generally increased with an increase of depth to $30 \mathrm{~cm}$; in the intermediate slope area $\left(25^{\circ}\right.$ and $\left.40^{\circ}\right)$ they had no evident trend; and in the steep slope area $\left(50^{\circ}\right.$ and $\left.60^{\circ}\right)$ they decreased with an increase of depth to $10 \mathrm{~cm}$ and $30 \mathrm{~cm}$, respectively. However with kaolinite, except in steeper slope areas where there was no diffraction peak, the height of the diffraction peak decreased with an increase of the depth.

Looking at the diffraction peak height of clay minerals in the weathering layer for different gradient classes (gentle, intermediate, and steep) with an increase of gradient class, it has been noticed that the average diffraction peak heights of clay minerals always decreased.

\section{Magnetic susceptibility}

Table III presents the magnetic test results of the soil samples at different depths for different slope gradients. The results showed that with an increase in depth, the magnetic susceptibility of the $25^{\circ}, 40^{\circ}$, and $60^{\circ}$ gradients changed slightly $\left(0.06-0.8410^{-8} \mathrm{~m}^{3} \mathrm{~kg}^{-1}\right)$, whereas in the $10^{\circ}, 15^{\circ}$, and $50^{\circ}$ gradients the changes were more substantial (up to 1.5-3.0 $10^{-8} \mathrm{~m}^{3} \mathrm{~kg}^{-1}$ ) with no obvious changing rule. However at a particular depth with an increase of slope gradient, the magnetic susceptibility mostly decreased. Thus, except in Layer II at $15^{\circ}$ and $60^{\circ}$ slope gradients, there was an obvious decreasing trend with an increase in slope gradient.

TABLE III

Average magnetic susceptibility in the weathering layer for different slope gradients and depths

\begin{tabular}{|c|c|c|c|c|c|c|c|}
\hline \multirow[t]{2}{*}{ Item } & \multirow[t]{2}{*}{ Layer $^{a)}$} & \multicolumn{6}{|c|}{ Slope gradient } \\
\hline & & $10^{\circ}$ & $15^{\circ}$ & $25^{\circ}$ & $40^{\circ}$ & $50^{\circ}$ & $60^{\circ}$ \\
\hline \multirow{5}{*}{$\begin{array}{l}\text { Magnetic } \\
\text { susceptibility }\end{array}$} & & \multicolumn{6}{|c|}{$10^{-8} \mathrm{~m}^{3} \mathrm{~kg}^{-1}$} \\
\hline & $I$ & 27.15 & 18.25 & 15.75 & 12.43 & 9.48 & 7.45 \\
\hline & II & 18.60 & 19.19 & 15.02 & 12.36 & 6.82 & 7.39 \\
\hline & III & 28.64 & 19.73 & 15.86 & 12.81 & - & - \\
\hline & IV & 28.07 & 20.76 & - & - & - & - \\
\hline
\end{tabular}

a) Depth of sampling layer: I is $0-10 \mathrm{~cm}$, II is $10-20 \mathrm{~cm}$, III is $20-30 \mathrm{~cm}$, and IV is greater than $30 \mathrm{~cm}$.

\section{DISCUSSION}

The results of the weathering layers of purple mudstone in the Three Gorges Reservoir area showed that the major chemical composition of purple mudstone in Three Gorges Reservoir area consisted of $\mathrm{Si}, \mathrm{Al}$, and $\mathrm{Ca}$ oxides (Table I), which accounted for $60-75 \%$ of the total. Besides three types of oxides mentioned earlier, it was also observed that $\mathrm{CaO}$ content was relatively high in the study area, which was due to the following two aspects: on the one hand, the strata of the Badong group of the Middle Triassic were mostly formed in a shallow sea environment with the clay itself having a high content of $\mathrm{Ca}$ and on the other, the surface biochemistry process was very complicated with dissolved $\mathrm{Ca}^{2+}$ being redeposited.

As for the weathering crust with the same parent rock material, the magnetic susceptibility reflected the pedogenesis extent: Generally, the magnetic susceptibility value increased with an increase of pedogenesis. So, in the study area, the sequence of the pedogenesis was, gentle slope $>$ intermediate slope $>$ steep slope. For the same slope gradient, with an increase in depth, clay mineral content and magnetic susceptibility changed very slightly, and there were no obvious trends (Tables II and III). This meant that the age of the weathering layer in the study area was very young and pedogenesis was weak.

Clay mineral composition testing showed that the mica and vermiculite-montmorillonite contents were not as well defined as kaolinite (Table II). Hence, the kaolinite peak height was used as a better indicator of soil pedogenesis in the weathering layer. The higher the peak height was, the more was 
the kaolinite content, and the stronger the pedogenesis the weaker the surface erosion. Based on these changing characteristics of clay minerals in the weathering layer, it could be stated that with an increase in slope gradient class, the pedogenesis in the weathering layer decreased. This meant that in the gentle slope area the pedogenesis was the strongest among the three followed by the intermediate slope area and finally the steep slope area.

At the same time, with an increasing slope gradient, the diffraction peak height (Table II) and magnetic susceptibility (Table III) of kaolinite decreased. This indicated that from a gentle to an intermediate and then to a steep slope, the pedogenesis of weathering layer was becoming weaker and weaker, while surface erosion was becoming stronger and stronger. This was mainly because gentle slopes were less vulnerable to erosion, and hence deposits were easily kept in the weathering layer, making pedogenesis relatively strong. However, on steep slopes, the strata were more vulnerable to mechanical erosion such as weight. Thus, fresh strata were often seen and the pedogenesis in the weathering layer was relatively weak.

To some extent, the weathering coefficient (Table I) could reflect the weathering degree from surface to lower depths. Nevertheless in the study area, the depth of the section was limited, and it was not very accurate to use this as a judgment standard. The testing results from this study should just be used as a reference.

Finally, in order to improve the analysis accuracy for the degree of weathering, some of the advanced methods such as isotope method of ${ }^{90} \mathrm{~S}_{r}$ and ${ }^{137} \mathrm{Cs}$ should be employed to determine the weathering speed and other factors.

\section{ACKNOWLEDGEMENTS}

Many thanks go to Dr. Li Xu-Sheng and Dr. Ren Zhao-Xia from the Department of Urban and Resources Science, Nanjing University for their assistance in sample collection, and also to Dr. John Daniels from the University of North Carolina at Charlotte, USA for correcting the Language mistakes in this article.

\section{REFERENCES}

Allen, C. E. 2005. Physical and Chemical Characteristics of Soils Forming on Boulder Tops, Kärkevagge, Sweden. Soil Science Society of America Journal. 69: 148-158.

Atkinson, J. H., Fookes, P. G., Miglio, B. F. and Pettifer, G. S. 2003. Destructuring and disaggregation of Mercia Mudstone during full-face tunnelling. Quarterly Journal of Engineering Geology and Hydrogeology. 36(4): $293-303$.

Cai, C. F., Ding, S. W. and Zhang, G. Y. 1996. Study on the nutrition current situation and loss of purple slope land in Three-Gorge Areas. Geographical Research (in Chinese). 15(3): 77-84.

Chong, J., Yang, D. Y. and Jiang, H. T. 2002. Preliminary researches on slope development in the Three-Gorges areas. Resources and Environment in the Yangtze Basin (in Chinese). 11(3): 264-268.

Clark, M. J. and Small, R. J. 1982. Slopes and Weathering. Cambridge University Press, Cambridge, England. 112pp.

Compiling Committee of Fengjie County in Sichuan Province. 1995. County Record of Fengjie (in Chinese). Local Record Press, Beijing. pp. 78-95.

Easterbrook, D. J. 1993. Surface Processes and Landforms. Macmillan Pub. Co. 520pp.

He, X. B. and Tang, K. L. 1998. Ultramicrostructures of zircon surface of Holocene soils on the loess plateau and its environments. Acta Pedologica Sinica (in Chinese). 35(3): 289-295.

He, Y., Liao, C. L., Xu, P. and Zhang, B. H. 2005. Zonal distribution of the erosion-landslide and soil micromorphological features in purple hilly region. Journal of Mountain Science. 2(1): 42-49.

Liang, Y., Shi, D., Yang, Y. S. and Lu, X. X. 1993. Water characteristics of erosion soils in Three Gorges region of the Yangtze River. Soils (in Chinese). 25(4): 201-204.

Liu, F., Xu, F. L. and Li, X. Y. 1996. Studies on clay minerals of mountain soils in Hubei and Hunan Porvinces (III)Clay minerals and surface chemical characteristics of soils on north slope of Shennongjia. Acta Pedologica Sinica (in Chinese). 33(1): 59-69.

Liu, J. G., Qian, Z. X. and Yang, Y. S. 1991. Studies on soil loss in slope cultivated lands with purple soil in the Yangtze Three-Gorge Region. Acta Conservationis Soil et Aquae Silvica (in Chinese). 5(3): 36-43.

Lu, S. G. 2000. Characterization of magnetism and iron oxide minerals of quaternary red earth and its paleoenvironmental implications. Acta Pedologica Sinica (in Chinese). 37(2): 182-191. 
Moreau, R. and Petard, J. 2004. Surface reactivity in tropical highly weathered soils and implications for rational soil management. Pedosphere. 14(4): 409-423.

Rech, J. A., Reeves, R. W. and Hendricks, D. M. 2001. The influence of slope aspect on soil weathering processes in the Spingerville volcanic field, Arizona. Catena. 43(1): 49-62.

Shi, B., Jiang, H. T., Liu, Z. B. and Fang, H. Y. 2002. Engineering geological characteristics of expansive soils in China. Engineering Geology. 67: 63-71.

Shi, B., Murakami, Y. and Wu, Z. S. 1998. Orientation of fine-grained soil: Quantification and application. Engineering Geology. 50: 59-70.

Shi, D. M., Yang, Y. S. and Li, X. X. 1991. An analysis of soil erosion rules and sediment producing sources in the region of Three-Gorge of the Yangtze River. Acta Conservationis Soil et Aquae Silvica. 5(3): 9-21.

Yang, Y. S. and Lu, X. X. 1992. Study on gravitational erosion in the Yangtze Three Gorges Region. Soils (in Chinese). 24(5): 228-233.

Yokota, S. and Iwamatsu, A. 2002. Weathering distribution in a steep slope of soft pyroclastic rocks as an indicator of slope instability. Engineering Geology. 55(1-2): 57-68.

Zhang, P. C., Yang, Q. K. and Xia, Y. H. 2002. Experimental study on soil erosion mechanism and process in middle and upper reaches of Chang Jiang River. Resource and environment in the Yangtze basin (in Chinese). 11(4): 376-381.

Zhang, Y., Peng, B. Z., Gao, X. and Yang, H. 2004. Degradation of soil properties due to erosion on sloping land in Southern Jiangsu Province, China. Pedosphere. 14(1): 17-26.

Zheng, D. and Shen, Y. C. 1998. Studies on process, restoration and management of the degrading slopelands--A case study of purple soil slopelands in the Three-Gorge Areas. Acta Geographica Sinica (in Chinese). 53(2): 116-122. 